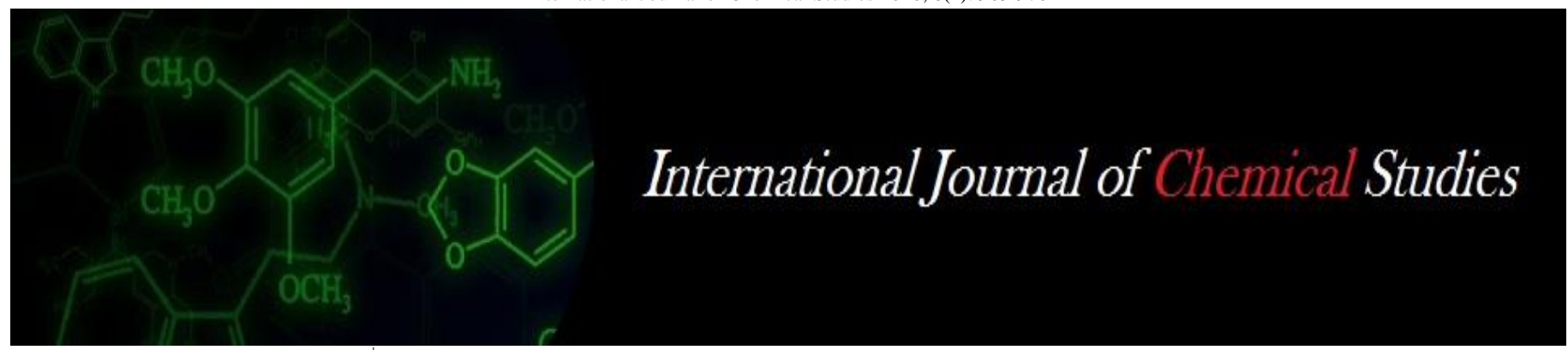

P-ISSN: 2349-8528

E-ISSN: 2321-4902

IJCS 2020; 8(1): 965-970

(C) 2020 IJCS

Received: 26-11-2019

Accepted: 30-12-2019

\section{AK Verma}

ICAR-Central Institute for Arid

Horticulture, Bikaner,

Rajasthan, India

\section{AK Mehta}

Jawaharlal Nehru Krishi Vishwa

Vidyalaya, Jabalpur, Madhya

Pradesh, India

\section{Sharma}

Jawaharlal Nehru Krishi Vishwa

Vidyalaya, Jabalpur, Madhya

Pradesh, India

RP Singh

Jawaharlal Nehru Krishi Vishwa Vidyalaya, Jabalpur, Madhya

Pradesh, India
Corresponding Author:

ICAR-Central Institute for Arid

Horticulture, Bikaner,

Rajasthan, India

\section{Genetic analysis of pod yield and its contributing traits in cowpea (Vigna unguiculata L. Walp)}

\author{
AK Verma, AK Mehta, D Sharma and RP Singh
}

DOI: https://doi.org/10.22271/chemi.2020.v8.i1m.8371

\begin{abstract}
The present investigation was undertaken to study the type of gene action involved for green pod yield and its components in cowpea and to estimate the general combining ability and specific combining ability of parents and crosses, respectively. The significance of both gca and sca variance for most of the characters indicated that both additive as well as non-additive types of gene actions were involved in the inheritance of these traits. The gca effects of parents suggested that 2014/COPBVAR-4, 2012/COPBVAR-2, 2014/COPBVAR-5 and Kashi Kanchan were good combiners for different yield components like number of flowers per cluster, number of pods per cluster, per cent pod set, number of pods per plant and days to last harvest. The Arka Garima, 2014/COPBVAR-5 and 2014/COPBVAR-4 were good general combiner for days to 50\% flowering and Kashi Kanchan, 2014/COPBVAR-5 and 2012/COPBVAR-2 for green pod yield per plant. No single parent was found to be good for all the traits. Based on specific combining ability effects of the hybrids, the cross combination2014/COPBVAR-5 x Gomti was found to be the best combination both for number of pods per plant and green pod yield per plant. The other best specific combinations were 2012/COPBVAR-3 x Pusa Komal, 2012/COPBVAR-5 x Pusa Komal and 2012/COPBVAR-2 x Arka Garima with high positive sca effects and high mean for green pod yield per plant. These promising parents can be used in future breeding programmes and the crosses may be exploited for isolation of transgressive segregants from the segregating generations of these crosses for further improvement of pod yield in cowpea.
\end{abstract}

Keywords: Cowpea, Combining ability, gca and sca effects, Vigna unguiculata, Yield

\section{Introduction}

The cowpea Vigna unguiculata (L.) Walp. the crop of round utilization is an important legume crop and forms an important component of farming systems throughout the tropics and warm sub-topics. Cowpea cultivars grown for the immature green pods which are used as vegetable are variously known as yard-long bean, asparagus bean and snake bean. Cowpea comes from the family leguminosae; sub family fabaceae and genus Vigna with chromosome number, $2 \mathrm{n}=$ 22. It has been known since the Vedic period in India which is considered as the primary Centre of Origin. The vegetable cowpea has been subdivided into three cultivated and two wild subspecies viz. unguiculata, sesquipedalis, cylindrica and dekindtiana and mensenensis, respectively (Verdcourt, 1970) ${ }^{[17]}$. It is prevalent by many vernacular names such as Lobia (Hindi), Barbati (Bengali), Alasande (Kannada), Urohi (Assami), Sonta (Garhwali), Chavati (Marathi)and Manpayar (Malayalam). Among legumes, cowpea is one of the most important vegetable crops grown during rainy and summer seasons. Tender pods as well as green-shelled seeds are used as vegetable and as a pulse when dried. It is also suitable for green manuring, fodder cover and catch crop. Cowpea is well adapted to stress and has excellent nutritive qualities. India holds second rank for producing vegetable in the world after China. Total production of vegetable in India is 169.04 million tonnes from an area of 10.10 million hectares and contributes about 13 per cent in total world production (Anonymous, 2017) ${ }^{[2]}$. Vegetable cultivation in India is mostly confined to small and marginal farmers. These farmers grow vegetables to get an additional income from small portion of their scarce land holdings which is comparatively better in soil and water status. The annual area cropped under cowpea and its total production in India is difficult to estimate, since it is rarely grown as single crop. However, the total production and yield per unit area has increased over the past decades. The area under cowpea is about 1.5 million hectare. Cowpea, which is a high protein vegetable, suffers from alarmingly low yield, especially in south-east Asia. 
One of the major reasons was recognized as non-availability of improved genotype suitable for different cropping systems with greater suitability and general adaptability. Although, large amount of variability is available for almost all the traits, even then very poor productivity for green pod yield had been recorded. Unavailability of desirable high yielding, disease and pest resistant varieties and non-adoption of advanced management practices are the major reasons responsible for low productivity. Hence, the high yield potential and quality are the main breeding objectives for improvement in this crop. For any crop improvement programme it is essential that sufficient variability exist for economically important traits in germplasm. Many workers have repeatedly emphasized the importance of genetic diversity in selecting the parents for recombination breeding in crops. Secondly, the most important pre-requisite for an effective breeding programme is identification of suitable parents which have good combining ability to produce desirable segregants in sufficient number, because it is not necessary that the high yielding parent will transmit its superiority to the progenies in the cross. Hence, it is necessary to know the genetic makeup of parents on the genetic contribution for yield and its contributing traits so that promising lines and superior crosses can be identified in early generation itself (Sharma et al. 2011) ${ }^{[14]}$. It is also needed to elucidate the genetic nature and magnitude of quantitative inherited traits and estimate prepotency of parents in hybrid combinations. Combining ability studies like line $\mathrm{x}$ tester analysis provides information in this direction. The study of general combining ability and specific combining ability helps in selection of superior parents and specific cross combinations, respectively. The information generated in this process is used to understand the magnitude of heterosis and relative importance of additive and non-additive gene actions. In the view of above, the present investigation was therefore undertaken with the objective to determine the general and specific combining ability of parents and hybrids, respectively along with gene action for green pod yield and its components.

\section{Materials and Methods}

The present investigation was carried out at Horticultural Research Farm, Department of Horticulture, Jawaharlal Nehru Krishi Vishwavidyalaya, Jabalpur, Madhya Pradesh, India during kharif 2014 and kharif 2015. Jabalpur is situated in "Kymore plateau and Satpura Hills" agro-climatic region of Madhya Pradesh. It falls on $23.9^{\circ}$ North latitude and $79.58^{\circ}$ East longitudes with an altitude of $411.8 \mathrm{~m}$ above mean sea level. The soil of the experimental field was medium black with good drainage, sandy loam in texture which is locally known as "Matasi" and was neutral in reaction with the $\mathrm{pH}$ 7.5. The experimental materials used in the study comprised of ten genotypes which were collected from different research institutes, eight from Indian Institute of Vegetable Research (IIVR), Varanasi, Arka Garima from IIHR, Bangalore and Pusa Komal from IARI, New Delhi. On the basis of genetic variability, correlation and path coefficient analysis and looking to desirable phenotypic contrasting characters and local market preference six lines (viz., 2014/COPBVAR-4, 2014/COPBVAR-5, 2014/COPBVAR-6, 2012/COPBVAR-2, 2012/COPBVAR-3 and 2012/COPBVAR-5) and four testers (viz., Pusa Komal, Arka Garima, Gomti and Kashi Kanchan) were chosen for Line $\mathrm{x}$ Testers crossing fashion to generate $24 \mathrm{~F}_{1}$ hybrids for the study of combining ability and gene action for qualitative and quantitative traits in cowpea. In
Kharif 2014 the selected lines and testers were grown in crossing block to generate F1s (crosses). Proper isolation of 3 $\mathrm{m}$ and bagging was done to check the chance of out crossing and mechanical mixture. During kharif 2015 and 2016 twenty-four $F_{1}$ 's including parents were raised in randomized block design with three replications to study combining ability on the basis of various growth and yield parameters. Each plot consisted of three rows of $3.15 \mathrm{~m}$ long and 7 plants in each row. The spacing given was $60 \mathrm{~cm}$ between rows and $30 \mathrm{~cm}$ within a row. Observations were recorded on five randomly selected tagged competitive plants from each entry. The observations for sixteen characters viz., plant height, number of branches per plant, days to first flowering, days to $50 \%$ flowering, number of flowers per cluster, number of pods per cluster, per cent pod set, days to first harvest, days to last harvest, pod length, pod width, pod weight, number of pods per plant, number of seeds per pod, 100 seed weight and green pod yield per plant were recorded on five plant basis in each replication. These observations were pooled over the years and subjected to statistical analysis. Combining ability analysis was carried out by the method suggested by Kempthorne, 1957.

\section{Results and discussion}

The analysis of variance for line $\mathrm{x}$ tester analysis (Table 1) revealed significant difference for all the characters for hybrids as well as parents vs. hybrids which indicated the presence of considerable variability among them for various growth and yield characters under study, however differences were not significant for all the characters. The mean square due to lines were recorded higher for number of branches per plant, days to first harvest, days to $50 \%$ harvest, number of pods/cluster, pod width and 100 seed weight suggesting the greater diversity among lines as compared to the testers, whereas rest of the characters had higher diversity than the lines. Similar findings were also reported by Pal et al. (2002) ${ }^{[10]}$ and Sharma et al. $(2011)^{[14]}$. The variance component ratio (gca/sca) was less than unity for number of branches per plant, days to firs flowering, days to $50 \%$ flowering, pods per cluster, days to first harvest, pod width and 100 seed weight which indicated the involvement of non-additive gene action (dominance or/epistasis) in the inheritance of these characters. Thus, heterosis breeding approach can be used to exploit available vigour in this crop. The variance was more than unity for plant height, flowers per cluster, per cent pod set, days to last harvest, number of pods per plant, pod length, pod weight, number of seeds per pod and pod yield per plant indicating the predominance of additive gene action. The value near to one obtained for all the characters in present study indicates high heritability of the traits and more importance of the additive gene effects than non-additive gene effects (Amiri-Oghan et al. 2009) ${ }^{[1]}$. Since the additive gene effects are fixable through direct selection, mass, pedigree and pure line selection on the $F_{1}$ generation of the crosses would be rewarding in the improvement of cowpea with increased number of pods per plant, seeds per pod and higher pod weight (Ayo-Vaughan et al. 2013) ${ }^{[3]}$.

The genetic value of the parents is adjudged on the basis of its combining ability. The combing ability had given useful information for selection of the parents in terms of expected performance of the crosses and their progenies. Also the parents having high gca effects could be useful for producing transgressive segregants in advance generation. General combining ability effects of lines and testers for different characters in cowpea are presented in Table 2. Negative gca 
effects are desirable for plant height as the crop habit is vine and the yields are related to the growth habit. Vine stemmed plant requires more space and staking whereas, more number of plants per unit area can be accommodated having bushy plant habit. Three lines, 2012/COPBVAR-5, 2012/COPBVAR-3 and 2014/COPBVAR-4 registered significant negative gca effect whereas, two lines 2012/COPBVAR-2 and 2014/COPBVAR-5 showed significant positive gca effects. Among the testers, three testers had significant negative gca effects for this trait. The canopy development depends on the number of branches per plant in terms to determine the green pod yield. Only two lines viz., 2012/COPBVAR-2 and 2014/COPBVAR-4 showed significant positive gca effect for branches per plant while, among testers, only one tester viz., Pusa Komal had positive significant gca effect. Early flowering is desirable character therefore, negative gca effect value is important for this character. The line, 2012/COPBVAR-3 showed the highest negative gca effect for days to first flowering. Similarly, for days to $50 \%$ flowering, the line 2014/COPBVAR-5 showed the highest negative gca effect for this character. The general combining ability effects in these parental lines indicated their importance in breeding of early genotypes. Among the testers, Arka Garima and Gomti had the highest negative gca effects. Breeding of early genotypes has been emphasized in cowpea by Singh et al. (2004) ${ }^{[15]}$, Pal et al. (2002) [10] and Manivannan and Sekar (2005) ${ }^{[9]}$ and contrary with Yadav et al. (2004) ${ }^{[18]}$. For days to first harvest, Arka Garima showed the highest negative gca effect among the testers whereas, the earliest days to first harvest was shown by 2014/COPBVAR-4 among the lines, both exhibited significant negative gca effect for this trait. The negative gca effect indicated their usefulness to get desirable lines of cowpea for early market.

For number of flowers per clusters, four lines showed significant gca effects and out of four, two lines viz., 2014/COPBVAR-6 and 2012/COPBVAR-3 had significant positive gca effects. Two testers showed significant positive gca effect viz., Arka Garima and Kashi Kanchan. High and significant positive gca effect was recorded in two lines viz. 2014/COPBVAR-5 and 2012/COPBVAR-2 for number of pods per clusters and on the other side two testers i.e., Kashi Kanchan and Arka Garima had significant positive gca effect. Among the lines, three lines viz., 2014/COPBVAR-5, 2014/COPBVAR-4 and 2012/COPBVAR-2 showed significant positive gca effect and only two testers showed positive gca effect i.e. Kashi Kanchan and Gomti for per cent pod set. For days to last harvest the maximum significant positive gca effect was shown by, 2012/COPBVAR-2 and 2014/COPBVAR-5 among the lines, whereas, Kashi Kanchan showed the highest significant positive effect among the testers. The positive gca effect can be utilized for developing/ breeding genotypes having long fruiting duration which is directly correlated to yield. Similar results were also reported by Singh et al. (2006) ${ }^{[16]}$, Pal et al. (2007) ${ }^{[10], ~ K w a y e ~}$ Romanus et al. (2008) ${ }^{[8]}$ and Sharma et al. (2011) ${ }^{[14]}$. Among the lines, two lines viz. 2014/COPBVAR-5 and 2012/COPBVAR-2 and on the other side only one tester i.e. Kashi Kanchan were found the best general combiner for number of pods per plant based on significant positive gca effects. For pod length, two lines had significant positive gca effects viz., 2014/COPBVAR-5 and 2012/COPBVAR-5 among the lines and on the other side only one tester had significant positive gca effect i.e. Kashi Kanchan. Among the lines, two lines had significant positive gca effects viz., 2014/COPBVAR-4 and 2014/COPBVAR-6 and on the other side only one tester i.e. Gomti had significant positive gca effect for pod width. For pod weight, three lines had significant positive gca effects viz., 2014/COPBVAR-4, 2012/COPBVAR-2 and 2012/COPBVAR-5 among the lines and on the other side two testers had significant positive gca effect i.e. Kashi Kanchan and Gomti. Among the lines two lines viz., 2012/COPBVAR-3 and 2012/COPBVAR-2 had significant positive gca effects and on the other side only one tester had significant positive gca effect for number of seeds per pod. For 100 seed weight, two lines had significant positive gca effects viz., 2012/COPBVAR-2 and 2014/COPBVAR-5 among the lines and on the other side only one tester i.e. Kashi Kanchan had significant positive gca effect. These results are in close conformity with the findings of Kumar and Sangwan (2005) ${ }^{[7]}$, Patel et al. (2013) ${ }^{[12]}$ and Selvakumar et al. (2014) ${ }^{[13]}$. Green pod yield per plant is the effect of the component characters related to it. Among the lines, two lines had significant positive gca effects viz., 2014/COPBVAR-5 and 2012/COPBVAR-2 and on the other side all the tester had significant positive gca effect except Gomti and Pusa Komal, indicates these parents and crosses will produce above average progenies. The parents 2014/COPBVAR-5, 2012/COPBVAR-2, Kashi Kanchan and Arka Garima were found to be best general combiners as they possessed significant and positive gca effects for pod yield along with other yield components. In addition to that, the lines and testers having high and significant gca effects in desirable direction could be used as parents in hybridization programs for genetic improvement of particular trait. The estimates of gca effects further exhibited that the parental lines having high gca effects for pod yield also had high to average gca effects for one or other yield components. Similar results have been observed by Danam and Chaudhary (2000) ${ }^{[4]}$ and Patel et al. (2013) ${ }^{[12]}$. These parents can be intensively used in the hybridization programme for improvement of pod yield in cowpea.

The estimates of specific combining ability (sca) effects of hybrids for pod yield and its component characters are given in Table 3. For plant height high negative sca effects were recorded for 2012/COPBVAR-3 x A. Garima, 2014/COPBVAR-4 x P. Komal, 2012/COPBVAR-3 x P. Komal and 2014/COPBVAR-6 x Gomti etc. High positive sca effects were recorded for 2014/COPBVAR-4 x A. Garima and 2012/COPBVAR-2 x Gomti that refers the non- additive gene action may also be responsible for the improvement of the number of branches per plant. Importance of non-additive gene action for this character was observed by Patel et al. $(2013)^{[12]}$ and Selvakumar et al. (2014) ${ }^{[13]}$. Among the twenty four crosses, 2012/COPBVAR-3 x A. Garima, 2012/COPBVAR-5 x P. Komal and 2012/COPBVAR-2 x Gomti showed highest negative sca effect being desirable for both days to first and days to $50 \%$ flowering. Similarly, for days to first harvest the hybrids/crosses 2012/COPBVAR-3 x A. Garima, 2014/COPBVAR-6 x K. Kanchan and 2012/COPBVAR-2 x Gomti recorded the highest significant negative heterosis for this trait. These results are in confirmation with Pal et al. (2002) ${ }^{[10]}$ and Sharma et al. (2011) ${ }^{[14]}$. The combinations of high $\mathrm{x}$ high, high $\mathrm{x}$ low and low x low general combiners produced significant sca effects suggesting thereby the involvement of non-allelic interactions. These results are similar to the findings of Singh et al. (2004) ${ }^{[15]}$ and Manivannan and Sekar (2005) ${ }^{[9]}$ and contrary with Yadav et al. (2004) ${ }^{[18]}$.

Twelve crosses showed significant positive sca effects for number of flowers per cluster, among them the top ranking 
crosses were, 2014/COPBVAR-6 x P. Komal, 2014/COPBVAR-5 x Gomti, 2012/COPBVAR-5 x A. Garima and 2012/COPBVAR-3 x K. Kanchan and six crosses i.e., 2012/COPBVAR-3 x P. Komal, 2014/COPBVAR-5 x Gomti, 2012/COPBVAR-2 x A. Garima and 2012/COPBVAR-5 x A. Garima for number of pods per cluster. These results indicate that the high mean performance of the hybrids is correlated with positive sca effects with hybrids having none or one or both of the parents with high gca effect, thus reinforcing the presence of additive as well as non-additive gene actions. Such behaviour has been ascribed to assemblage of genes in crosses preferring clustering habit and confirms additiveness. These results are in confirmation with Yadav et al. (2004) ${ }^{[18]}$ and Selvakumar et al. (2014) ${ }^{[13]}$. For per cent pod set, six crosses showed significant positive sca effect and the highest significant positive sca effect was exhibited by the cross 2014/COPBVAR-4 x P. Komal followed by 2012/COPBVAR-2 x A. Garima, 2012/COPBVAR-3 x P. Komal and 2012/COPBVAR-5 x K. Kanchan. The highest significant and positive sca effects for days to last harvest were shown by the hybrids/crosses, 2014/COPBVAR-4 x A. Garima followed by 2014/COPBVAR-5 x Gomti and 2012/COPBVAR-2 x A. Garima. These results are similar to the findings of Kumar and Sangwan (2005) ${ }^{[7]}$ and Sharma et al. $(2011)^{[14]}$.

In case of pods per plant, high positive sca effects were shown by eight crosses; some of these were 2014/COPBVAR-5 x Gomti, 2012/COPBVAR-2 x A. Garima, 2012/COPBVAR-5 x K. Kanchan and 2012/COPBVAR-3 x P. Komal. Among these, 2014/COPBVAR-5 $\mathrm{x}$ Gomti had high mean performance for this trait. Two parents of first two crosses had high positive gca effect with high sca effects while, other two crosses recorded high sca without having high gca of parents. Most of the above crosses had negative or lower gca effects other than one of the parent of them which had positive gca effects. These results are in confirmation with Manivannan and Sekar (2005) ${ }^{[9]}$ and Singh et al. (2006) ${ }^{[16]}$. For pod length, high positive sca effects were shown by 2012/COPBVAR-5 x P. Komal, 2014/COPBVAR-4 x A. Garima and 2014/COPBVAR-4 x K. Kanchan. Among these only two hybrids showed high mean performance and high gca effects exhibited by one of the parent that attributed to importance of additive gene action and possibility of getting better transgressive segeregants for early generation testing. Similar findings were observed by Singh et al. (2004) ${ }^{[15]}$ and Kumar and Sangwan (2005) ${ }^{[7]}$. Contrary reports were also given by Manivannan and Sekar (2005) ${ }^{[9]}$. High significant and positive sca effects for pod width were shown by only two crosses viz. 2012/COPBVAR-3 x Gomti. The crosses showed high mean performance with at least one of the parent had significant gca effect. In case of pod diameter, high positive sca effects were showed by eight crosses; some of these were 2012/COPBVAR-3 x P. Komal, 2012/COPBVAR5 x P. Komal and 2014/COPBVAR-4 x A. Garima. Among these, some crosses showed high mean performance and some lower mean performance for this trait. At least one parent of these crosses had high positive gca effect with or without high sca effects. One of the parents of some above crosses recorded positive gca effects but some of them had negative gca effects also thereby, corroborating the presence of nonadditive gene action (over dominance and epistasis) for crosses having high sca effects. These findings are similar to the reports of Yadav et al. (2004) ${ }^{[18]}$. For number of seeds per pod, five crosses showed high positive sca effects. Most of the crosses having 2012/COPBVAR-3 and 2012/COPBVAR-5 with common tester, which showed high gca effects, revealed additive gene action, therefore, this character can be improved through selection. These findings are in agreement Singh et al. (2006) ${ }^{[16]}$. Contrary report was also given by Kumar and Sangwan (2005) ${ }^{[7]}$. In case of 100 seed weight, five crosses showed high positive sca effects viz., 2014/COPBVAR-5 x Gomti, 2012/COPBVAR-2 x A. Garima, 2012/COPBVAR-5 $x$ P. Komal, 2012/COPBVAR-3 x P. Komal and 2014/COPBVAR-4 x A. Garima. These findings are in agreement with Selvakumar et al. (2014) ${ }^{[13]}$ and Idahosa and Alika (2013) ${ }^{[5]}$.

For pod yield per plant, six crosses showed high positive sca effects viz., 2014/COPBVAR-5 x Gomti, 2012/COPBVAR-3 x P. Komal, 2012/COPBVAR-5 x P. Komal, 2012/COPBVAR-2 x A. Garima, 2014/COPBVAR-4 x A. Garima and 2012/COPBVAR-5 x K. Kanchan. Among these crosses 2014/COPBVAR-6 x P. Komal, 2014/COPBVAR-6 x K. Kanchan, 2014/COPBVAR-6 x Gomti, 2014/COPBVAR5 x P. Komal and 2014/COPBVAR-5 x Gomti had high mean performances but only two parents had significant gca effect. In addition to gca and sca performance array mean of the parents and per se performance of the crosses, respectively to be looked in to for yield characteristics. This indicate that suitable combiners/parents/ testers could be selected on the basis of array means, its self and selection of hybrid/ cross on the basis of per se performance seems to be more reliable than selection based on sca effect. Finally it's per se performance is the true realised mean for cross/ hybrid. These findings are in agreement with Pal et al. (2002) ${ }^{[10]}$, Yadav et al. (2004) ${ }^{[18]}$. Contrary reports were also given by Kumar and Sangwan (2005) ${ }^{[7]}$ and Singh et al. (2006) ${ }^{[16]}$. The predominance of both additive and dominance gene actions involvement in the characters studied should be considered when developing improvement programmes in selecting superior parents. In the present study, parents viz., 2012/COPBVAR-2, 2014/COPBVAR-5, Kashi Kanchan and Arka Garima were found the best general combiners for pod yield and yield contributing traits. These lines could be utilized in cowpea improvement/hybridization programme to exploit heterosis. Similarly, the most promising specific combiners for pod yield and yield components were 2014/COPBVAR-5 x Gomti, 2012/COPBVAR-3 x P. Komal based on per se performance of parents and the sca values of the hybrids. These crosses (based on sca effects) generally involved at least one parent with desirable gca effects. It is therefore, suggested that these promising parents and crosses may be exploited for further improvement of pod yield in cowpea.

Table 1: Analysis of variance for Line $\mathrm{x}$ Tester analysis for green pod yield and its component characters in cowpea

\begin{tabular}{|c|c|c|c|c|c|c|c|c|}
\hline \multirow{2}{*}{ S. No. } & \multirow{2}{*}{ Character } & & Replication & Hybrids & Lines & Testers & Lines vs Testers & Error \\
\cline { 3 - 7 } & & $\mathbf{d f}$ & $\mathbf{0 2}$ & $\mathbf{2 3}$ & $\mathbf{0 5}$ & $\mathbf{0 3}$ & $\mathbf{1 5}$ \\
\hline 1. & Plant height $(\mathrm{cm})$ & 6.306 & $1363.257^{* *}$ & 1193.717 & 3154.463 & $1061.529^{* *}$ & 4.796 \\
\hline 2. & Number of branches/plant & 0.234 & $3.015^{* *}$ & $5.102^{*}$ & $8.235^{* *}$ & $1.275^{* *}$ & 0.473 \\
\hline 3. & Days to first flowering & 1.215 & $32.464^{* *}$ & 5.209 & $122.358^{*}$ & $23.570^{* *}$ & 2.599 \\
\hline 4. & Days to 50\% flowering & 2.256 & $50.257^{* *}$ & 47.335 & $124.159^{*}$ & $36.451^{* *}$ & 2.786 \\
\hline 5. & Number of flowers/cluster & 0.537 & $2.443^{* *}$ & 2.414 & 5.760 & $1.789^{* *}$ & 0.147 \\
\hline
\end{tabular}




\begin{tabular}{|c|c|c|c|c|c|c|c|}
\hline 6. & Number of pods/cluster & 0.003 & $1.124^{* *}$ & 1.129 & $3.665^{* *}$ & $0.614^{* *}$ & 0.067 \\
\hline 7. & Pod setting percentage & $40.690^{*}$ & $350.083^{* *}$ & 595.927 & 320.668 & $274.030^{* *}$ & 11.606 \\
\hline 8. & Days to first harvest & 2.927 & $128.916^{* *}$ & $234.140^{*}$ & 205.411 & $78.542^{* *}$ \\
\hline 9. & Days to last harvest & 0.423 & $499.746^{* *}$ & 483.373 & 1079.097 & $389.334^{* *}$ & 7.524 \\
\hline 10. & Number of pods per plant & $20.834^{* *}$ & $307.892^{* *}$ & 353.375 & 443.072 & $265.695^{* *}$ & 3.043 \\
\hline 11. & Pod length (cm) & 3.706 & $44.081^{* *}$ & 21.774 & 22.043 & $55.925^{* *}$ & 1.161 \\
\hline 12. & Pod width (cm) & 0.005 & $0.036^{* *}$ & $0.067^{*}$ & $0.079^{*}$ & $0.017^{* *}$ & 0.005 \\
\hline 13. & Pod weight (g) & $20.850^{* *}$ & $374.323^{* *}$ & 290.708 & 599.093 & $357.240^{* *}$ & 3.053 \\
\hline 14. & Number of seeds per pod & $1.363^{*}$ & $3.882^{* *}$ & 3.072 & 3.672 & $4.194^{* *}$ & 0.279 \\
\hline 15. & 100 seed weight (g) & $9.822^{*}$ & $36.702^{* *}$ & 38.462 & $112.660^{*}$ & $20.924^{* *}$ & 2.337 \\
\hline 16. & Green pod yield /plant (g) & 401.315 & $5067.269^{* *}$ & 3717.879 & 12049.100 & $4120.698^{* *}$ & 186.736 \\
\hline
\end{tabular}

Table 2: General combining ability (gca) effects of lines and testers for green pod yield and its component characters

\begin{tabular}{|c|c|c|c|c|c|c|c|c|c|c|c|c|c|c|c|c|}
\hline \multirow{2}{*}{ Parents } & \multicolumn{16}{|c|}{ Characters } \\
\hline & 1 & 2 & 3 & 4 & 5 & 6 & 7 & 8 & 9 & 10 & 11 & 12 & 13 & 14 & 15 & 16 \\
\hline \multicolumn{17}{|c|}{ Lines } \\
\hline 2012/COPBVAR-5 & $-1.365^{* *}$ & 0.224 & 0.505 & $2.232^{* *}$ & $-.431^{* *}$ & $-.233^{* *}$ & 0.264 & $4.362^{* *}$ & $-6.968^{* * 2}$ & $-.610^{* *}$ & $1.078^{* *}$ & $-.113^{* *}$ & $3.801^{* *}$ & -0.229 & $-.207^{* *}$ & -4.508 \\
\hline 2012/ COPBVAR-3 & $-4.874^{* *}$ & $-0.648^{* *}$ & $-0.924^{*}$ & 0.334 & $0.309^{* * *}$ & -0.026 & $-5.222^{* * 1}$ & $3.344^{* * *}$ & $1.117^{*}$ & 0.371 & $-1.986^{* *}$ & -0.039 & $-6.051^{*+1}$ & $0.723^{* *}$ & -0.032 & 6.028 \\
\hline 2014/ COPBVAR-6 & -1.038 & $-.656^{* *}$ & $0.969^{*}$ & $2.373^{* *}$ & $0.549^{* *}$ & $-.273^{* *}$ & $-1.404^{* * 1}$ & $3.804^{* * *}$ & $-4.558^{* * 1}$ & $-7.123^{* *}$ & -0.221 & $0.049^{*}$ & -0.943 & $-0.685^{* *}$ & $-2.342^{*}$ & $-25.403^{* *}$ \\
\hline 2014/ COPBVAR-4 & $-6.906^{* *}$ & $0.797^{* *}$ & -0.176 & $-1.629^{* *}$ & $-0.634^{* *}$ & $-0.228^{*}$ & $5.739^{* *}$ & $-6.093^{* *}$ & $-3.998^{* * 2}$ & $-3.830^{* *}$ & 0.451 & $0.102^{* *}$ & $5.164^{* *}$ & -0.019 & -0.597 & $-12.943^{* *}$ \\
\hline 2012/ COPBVAR-2 & $10.808^{* *}$ & $0.666^{* *}$ & -0.081 & $-1.513^{* *}$ & 0.109 & $0.335^{* *}$ & $4.429^{* *}$ & $-3.441^{* * *}$ & $9.890^{* *}$ & $4.550^{* *}$ & $-0.980^{* * *}$ & 0.022 & $3.519^{* *}$ & $0.431^{* *}$ & $2.091^{* * *}$ & $17.521^{* *}$ \\
\hline 2014/ COPBVAR-5 & $13.375^{* *}$ & $-0.383^{*}$ & -0.293 & $-1.897^{* *}$ & 0.099 & $0.404^{* *}$ & $6.194^{* *}$ & $-1.976^{* *}$ & $3.917^{* *}$ & $7.642^{* *}$ & $1.659^{* *}$ & -0.021 & $-5.489^{* * *}$ & -0.222 & $2.087^{* *}$ & $19.305^{* * *}$ \\
\hline \multicolumn{17}{|c|}{ Testers } \\
\hline Gomti & $-3.569^{* *}$ & -0.165 & $-1.415^{* *}$ & $-1.183^{* *}$ & $-0.782^{* *}$ & $-0.398^{*}$ & $1.971^{* *}$ & -0.774 & $-5.081^{* *}$ & $-4.578^{* * n}$ & -0.415 & $0.083^{* *}$ & $4.665^{* *}$ & $-0.411^{* *}$ & $-2.374^{*}$ & $-21.379^{* *}$ \\
\hline Pusa Komal & $-3.033^{* *}$ & $0.806^{* *}$ & $2.971^{* *}$ & $2.961^{* *}$ & -0.051 & $-0.375^{*}$ & $-5.836^{* *}$ & $3.153^{* *}$ & $-1.190^{* *}$ & $-2.973^{*+1}$ & $-0.946^{* *}$ & $-0.079^{* *}$ & $-6.531^{\text {*** }}$ & $-0.267^{*}$ & $-1.218^{*}$ & $-22.670^{* *}$ \\
\hline Kashi Kanchan & $18.165^{* *}$ & 0.174 & $1.266^{* *}$ & $1.227^{* *}$ & $0.406^{* *}$ & $0.468^{* *}$ & $3.935^{* *}$ & $2.041^{* * *}$ & $11.289^{*}$ & $6.563^{* *}$ & $1.597^{* *}$ & 0.000 & $5.037^{* *}$ & 0.073 & $3.409^{* *}$ & $27.813^{* *}$ \\
\hline Arka Garima & $-1.563^{* *}$ & $-0.816^{* *}$ & $-2.822^{* *}$ & $-3.004^{* *}$ & $0.426^{* *}$ & $0.305^{* *}$ & -0.070 & $-4.419^{* *}$ & $-5.018^{* *}$ & $0.988^{*}$ & -0.236 & -0.005 & $-3.171^{\text {*** }}$ & $0.605^{* *}$ & 0.184 & $16.237^{* *}$ \\
\hline SE (Lines) & 0.606 & 0.170 & 0.430 & 0.462 & 0.102 & 0.065 & 0.873 & 0.602 & 0.758 & 0.526 & 0.312 & 0.019 & 0.502 & 0.144 & 0.383 & 3.417 \\
\hline SE (Testers) & 0.495 & 0.139 & 0.351 & 0.377 & 0.083 & 0.053 & 0.713 & 0.491 & 0.429 & 0.429 & 0.254 & 0.015 & 0.410 & 0.117 & 0.312 & 2.790 \\
\hline
\end{tabular}

Table 3: Specific combining ability (sca) effects of hybrids for green pod yield and its component characters

\begin{tabular}{|c|c|c|c|c|c|c|c|c|}
\hline \multirow{2}{*}{ Hybrids } & \multicolumn{8}{|c|}{ Characters } \\
\hline & 1 & 2 & 3 & 4 & 5 & 6 & 7 & 8 \\
\hline 2012/COPBVAR-5xGomti & $14.642 * *$ & 0.510 & 1.553 & 0.518 & -0.371 & $-0.325^{*}$ & -1.571 & -0.399 \\
\hline 2012/ COPBVAR-5xP. Komal & $1.805 * *$ & -0.311 & $-3.893 * *$ & $-3.056 * *$ & 0.088 & -0.167 & $-7.864 * *$ & -1.903 \\
\hline 2012/ COPBVAR-5x K. Kanchan & $37.213 * *$ & 0.571 & $2.043^{*}$ & $1.958^{*}$ & $-0.459 *$ & 0.079 & $10.358 * *$ & 1.716 \\
\hline 2012/ COPBVAR-5x A. garima & $20.766^{* *}$ & $-0.769^{*}$ & 0.297 & 0.579 & $0.741 * *$ & $0.413^{* *}$ & -0.923 & 0.586 \\
\hline 2012/ COPBVAR-3 x Gomti & 1.021 & -0.348 & $2.322 * *$ & $4.586 * *$ & $-0.751 * *$ & $-0.463 * *$ & -0.938 & $4.819 * *$ \\
\hline 2012/ COPBVAR-3 xP. Komal & $-14.242 * *$ & -0.258 & 0.727 & 0.882 & 0.158 & $0.785 * *$ & $12.389 * *$ & -0.328 \\
\hline 2012/ COPBVAR-3 xK. Kanchan & $34.946 * *$ & 0.373 & 1.162 & 0.906 & $0.711 * *$ & $0.272^{*}$ & -2.148 & $3.804 * *$ \\
\hline 2012/ COPBVAR-3 xA. Garima & $-21.725 * *$ & 0.233 & $-4.211 * *$ & $-6.374 * *$ & -0.119 & $-0.595 * *$ & $-9.303 * *$ & $-8.296 * *$ \\
\hline 2014/ COPBVAR-6 xGomti & $-14.055 * *$ & -0.080 & -0.990 & 1.397 & -0.121 & 0.154 & 1.687 & $5.109 * *$ \\
\hline 2014/ COPBVAR-6 xP. Komal & $22.502 * *$ & 0.289 & 0.544 & $1.933 *$ & $1.618^{* *}$ & 0.232 & $-9.656 * *$ & $5.672 * *$ \\
\hline 2014/ COPBVAR-6 x K. Kanchan & $-4.090 * *$ & -0.249 & -0.721 & $-2.297 *$ & $-0.809 * *$ & -0.261 & 3.203 & $-6.856 * *$ \\
\hline 2014/ COPBVAR-6 x A. Garima & $-4.357 * *$ & 0.041 & 1.167 & -1.033 & $-0.689 * *$ & -0.125 & $4.765^{* *}$ & $-3.926^{* *}$ \\
\hline 2014/ COPBVAR-4 x Gomti & $-3.788 * *$ & $-1.213 * *$ & -1.096 & -0.751 & -0.088 & $0.199 * *$ & $8.718^{* *}$ & -1.483 \\
\hline 2014/ COPBVAR-4 x P. Komal & $-15.224 * *$ & -0.233 & $3.532 * *$ & $2.239^{*}$ & $-0.899 * *$ & 0.027 & $13.642 * *$ & $2.900^{*}$ \\
\hline 2014/ COPBVAR-4 x K. Kanchan & $13.945 * *$ & 0.358 & -0.747 & -1.358 & $0.464 *$ & -0.203 & $-12.856^{* *}$ & -2.238 \\
\hline 2014/ COPBVAR-4 x A. Garima & $5.067 * *$ & $1.088 * *$ & -1.689 & -0.130 & $0.524 *$ & -0.023 & $-9.504 * *$ & 0.822 \\
\hline 2012/ COPBVAR-2 xGomti & $-2.701^{*}$ & 0.655 & $-3.890 * *$ & $-6.067 * *$ & 0.402 & -0.233 & $-9.676 * *$ & $-6.826^{* *}$ \\
\hline 2012/ COPBVAR-2 x P. Komal & $9.263 * *$ & -0.033 & -1.576 & $-2.211 *$ & $-0.633 * *$ & $-0.522 * *$ & $-3.902 *$ & $-3.353 * *$ \\
\hline 2012/ COPBVAR-2 x K. Kanchan & $-5.085 * *$ & -0.411 & 1.129 & $2.523 * *$ & 0.361 & $0.271^{*}$ & 0.660 & $3.359 * *$ \\
\hline 2012/ COPBVAR-2 x A.Garima & -1.477 & -0.211 & $4.337 * *$ & $5.754 * *$ & -0.129 & $0.484 * *$ & $12.918 * *$ & $6.819 * *$ \\
\hline 2014/ COPBVAR-5 xGomti & $4.882 * *$ & 0.477 & $2.101 *$ & 0.317 & $0.929 * *$ & $0.668 * *$ & 1.780 & -1.221 \\
\hline 2014/ COPBVAR-5 x P. Komal & $-4.105 * *$ & 0.547 & .0666 & 0.213 & -0.332 & $-0.355 * *$ & $-4.610 *$ & $-2.988 *$ \\
\hline 2014/ COPBVAR-5 x K. Kanchan & $-2.503 * *$ & -0.642 & $-2.866^{* *}$ & -1.733 & -0.269 & -0.158 & 0.783 & 0.214 \\
\hline 2014/ COPBVAR-5 x A. Garima & 1.726 & -0.382 & 0.099 & 1.204 & -0.329 & -0.155 & 2.047 & $3.994 * *$ \\
\hline $\mathrm{CD} 95 \% \mathrm{SCA}$ & 2.441 & 0.687 & 1.734 & 1.860 & 0.413 & 0.262 & 3.518 & 2.425 \\
\hline
\end{tabular}

$*, * *=$ significant at $5 \%$ and $1 \%$ levels of significance, respectively

Table 4: Specific combining ability (sca) effects of hybrids for green pod yield and its component characters

\begin{tabular}{|c|c|c|c|c|c|c|c|c|}
\hline \multirow{2}{*}{ Hybrids } & \multicolumn{9}{|c|}{ Characters } \\
\cline { 2 - 8 } & $\mathbf{9}$ & $\mathbf{1 0}$ & $\mathbf{1 1}$ & $\mathbf{1 2}$ & $\mathbf{1 3}$ & $\mathbf{1 4}$ & $\mathbf{1 5}$ & $\mathbf{1 6}$ \\
\hline 2012/COPBVAR-5xGomti & $-8.544^{* *}$ & $-10.293^{* *}$ & $-2.668^{* *}$ & 0.052 & $-6.793^{* *}$ & -0.054 & $-1.833^{*}$ & $-34.660^{* * *}$ \\
\hline 2012/ COPBVAR-5xP. Komal & $13.565^{* *}$ & $6.285^{* *}$ & $5.397^{* *}$ & 0.014 & $14.904^{* *}$ & $1.732^{* *}$ & $2.791^{* *}$ & $35.441^{* *}$ \\
\hline 2012/ COPBVAR-5x K. Kanchan & $7.286^{* *}$ & $9.538^{* *}$ & 0.044 & $-0.085^{*}$ & 0.176 & 0.492 & 1.494 & $19.168^{* *}$ \\
\hline 2012/ COPBVAR-5x A. garima & $-12.307^{* *}$ & $-5.576^{* *}$ & $-2.773^{* *}$ & 0.020 & $-8.287^{* *}$ & $-2.170^{* *}$ & $-2.451^{* *}$ & $-19.949^{* *}$ \\
\hline 2012/ COPBVAR-3 xGomti & $5.171^{* *}$ & -0.791 & $-5.070^{* *}$ & $0.134^{* *}$ & $-10.440^{* *}$ & -0.507 & $-2.138^{*}$ & $-33.606^{* *}$ \\
\hline
\end{tabular}




\begin{tabular}{|c|c|c|c|c|c|c|c|c|}
\hline 2012/ COPBVAR-3 xP. Komal & $6.980 * *$ & $9.434 * *$ & $4.031 * *$ & -0.061 & $20.256^{* *}$ & $-0.720 *$ & $2.656 * *$ & $52.045^{* *}$ \\
\hline 2012/ COPBVAR-3 xK. Kanchan & -3.049 & $-4.432 * *$ & -0.782 & -0.009 & 1.018 & $-0.920 * *$ & 0.219 & -9.438 \\
\hline 2012/ COPBVAR-3 xA. Garima & $-9.102 * *$ & $-4.211 * *$ & $1.821 * *$ & -0.064 & $-10.834 * *$ & $2.147 * *$ & -0.736 & -9.002 \\
\hline 2014/ COPBVAR-6 xGomti & $-4.954 * *$ & $3.203 * *$ & $3.725 * *$ & -0.011 & $8.121 * *$ & $0.632 *$ & 0.992 & 9.425 \\
\hline 2014/ COPBVAR-6 xP. Komal & $3.085^{*}$ & $-2.902 * *$ & $-3.964 * *$ & 0.041 & $-11.522 * *$ & 0.028 & 1.076 & $-15.424 *$ \\
\hline 2014/ COPBVAR-6 x K. Kanchan & $3.626^{*}$ & -1.938 & -0.247 & -0.008 & -1.420 & 0.168 & -1.371 & 10.563 \\
\hline 2014/ COPBVAR-6 x A. Garima & -1.757 & 1.637 & 0.486 & -0.023 & $4.821 * *$ & $-0.828 * *$ & -0.696 & -4.564 \\
\hline 2014/ COPBVAR-4 x Gomti & $-8.174 * *$ & -2.089 & $-3.728 * *$ & $-0.113 * *$ & $-5.155 * *$ & -0.124 & -1.443 & $-15.278^{*}$ \\
\hline 2014/ COPBVAR-4 x P. Komal & $-13.895 * *$ & $-5.695 * *$ & $-6.036 * *$ & -0.031 & $-7.359 * *$ & -0.538 & $-2.429 * *$ & $-26.234 * *$ \\
\hline 2014/ COPBVAR-4 x K. Kanchan & $3.676^{*}$ & 1.770 & $4.480 * *$ & $0.090 *$ & $2.193^{*}$ & -0.228 & $1.594 *$ & 13.233 \\
\hline 2014/ COPBVAR-4 x A. Garima & $18.393^{* *}$ & 6.014 & $5.284 * *$ & 0.055 & $10.321 * *$ & $0.890 * *$ & $2.279 * *$ & $28.279 * *$ \\
\hline 2012/ COPBVAR-2 xGomti & 0.749 & $-3.469 * *$ & $4.447 * *$ & 0.007 & $5.730 * *$ & 0.346 & -0.731 & 12.122 \\
\hline 2012/ COPBVAR-2 x P. Komal & $-6.343 * *$ & $-14.005 * *$ & -0.345 & -0.001 & $-12.174 * *$ & $-0.928 * *$ & $-1.587 *$ & $-55.347 * *$ \\
\hline 2012/ COPBVAR-2 x K. Kanchan & $-8.291 * *$ & $4.510 * *$ & 0.032 & -0.060 & $-2.882 * *$ & -0.448 & -1.104 & 10.780 \\
\hline 2012/ COPBVAR-2 x A.Garima & $13.885 * *$ & $12.964 * *$ & $-4.135 * *$ & 0.055 & $9.326 * *$ & $1.030 * *$ & $3.421 * *$ & $32.446 * *$ \\
\hline 2014/ COPBVAR-5 xGomti & $15.751 * *$ & $13.438^{* *}$ & $3.295^{* *}$ & -0.070 & $8.537 * *$ & -0.292 & $5.153 * *$ & $61.998 * *$ \\
\hline 2014/ COPBVAR-5 x P. Komal & $-3.390 *$ & $6.883^{* *}$ & 0.916 & 0.039 & $-4.106 * *$ & 0.425 & $-2.507 * *$ & 9.519 \\
\hline 2014/ COPBVAR-5 x K. Kanchan & $-3.249 *$ & $-9.493 * *$ & $-3.527 * *$ & 0.073 & 0.916 & $0.935 * *$ & -0.831 & $-44.308 * *$ \\
\hline 2014/ COPBVAR-5 x A. Garima & $-9.112 * *$ & $-10.828 * *$ & -0.684 & -0.042 & $-5.347 * *$ & $-1.068 * *$ & $-1.816^{*}$ & $-27.209 * *$ \\
\hline CD 95\% SCA & 3.055 & 2.118 & 1.257 & 0.078 & 2.023 & 0.581 & 1.543 & 13.758 \\
\hline
\end{tabular}

$*, * *=$ significant at $5 \%$ and $1 \%$ levels of significance, respectively

\section{Acknowledgement}

The authors are thankful to ICAR-Indian Institute of Vegetable Research, Varanasi for providing the seed material of genotypes and Jawaharlal Nehru Krishi Vishwa Vidyalaya, Jabalpur, India for providing research facility and support to carry out the research work.

\section{References}

1. Amiri-Oghan H, Fatokian MH, Javidfar F, Alizadeh B. Genetic analysis of grain yield, days to flowering and maturity in oilseed rape (Brassica napus L.) using diallel crosses. International Journal of Plant Production. 2009; 3:19-26.

2. Anonymous. Horticulture Statistics at a Glance. Horticulture Statistics Division, Department of Agriculture, Cooperation \& Farmers Welfare, Ministry of Agriculture \& Farmers Welfare, Government of India, 2017.

3. Ayo-Vaughan MA, Ariyo OJ, Alake CO. Combining ability and genetic components for pod and seed traits in cowpea lines. Italian Journal of Agronomy. 2013; 8(e10):73-78.

4. Danam S, Chaudhari FP. Selection of superior combiners in cowpea. Crop Research. 2000; 20(2):268-273.

5. Idahosa DO, Alika JE. Diallel analysis of six agronomic characters in vigna unguiculata genotypes. African Journal of Plant Breeding. 2013; 1(1):001-007.

6. Kempthorne O. An introduction to genetic statistics. John Wiley and Sons Inc., New York, 1957.

7. Kumar D, Sangwan VP. Combining ability studies for yield and architectural traits in cowpea [Vigna unguiculata (L.) Walp.]. Annals of Biology. 2005; 21(1):47-49.

8. Kwaye G, Hussein RS, Mashela WP. Combining ability analysis and association of yield and yield components among selected cowpea lines. Euphytica. 2008; 162(2):205-210.

9. Manivannan R, Sekar K. Combining ability for yield and different quality traits in vegetable cowpea (Vigna unguiculata (L.) Walp.). Indian Journal of Horticulture. 2005; 62(2):196-199.

10. Pal AK, Ram D, Morya AN, Rajput CBS. Combining ability for green pod yield and its traits in cowpea. Indian Journal of Horticulture. 2002; 59(4):395-401.
11. Pal AK, Kumar S, Maurya AN. Genetic study for earliness in cowpea (Vigna unguiculata L. Walp.). Indian Journal of Horticulture. 2007; 64(1):63-66.

12. Patel NB, Desai RT, Patel BN, Koladiya PB. Combining ability study for seed yield in cowpea [Vigna unguiculata (L.) Walp]. The Bioscan. 2013; 8(1):139-142.

13. Selvakumar G, Anandakumar CR, Chinniah C, Ushakumari R. Combining ability analysis in the inter sub specific crosses of cowpea (Vigna unguiculata) and yard long bean (Vigna unguiculata spp. sesquipedalis). Electronic Journal of Plant Breeding. 2014; 5(2):187-191.

14. Sharma D, Mehta N, Trivedi J, Gupta CR. Combining ability analysis for green pod yield and its components in inter sub-species of cowpea Vigna unguiculata (L) Walp. ssp. Vegetable Science. 2011; 38(2):156-162.

15. Singh SP, Kumar R, Joshi AK, Singh B. Genetic architecture of yield traits in cowpea [Vigna unguiculata (L.) Walp.]. Advances in Plant Science. 2004; 17(2):495502 .

16. Singh I, Badaya SN, Tikka SBS. Combining ability for yield over environments in cowpea (Vigna unguiculata (L.) Walp.). Indian Journal of Crop Science. 2006; 1(12):205-206.

17. Verdcourt B. Studies in the leguminosae-Papilionoideae for the flora of tropical East Africa. Kew. Bulletin. 1970; 24:507.

18. Yadav KS, Yadava HS, Naik ML. Gene action governing the inheritance of pod yield in cowpea. Legume Research. 2004; 27(1):66-69. 